\title{
EFFECTS OF CROP GEOMETRY AND NUTRIENT MANAGEMENT ON NUTRIENT UPTAKE AND QUALITY PARAMETERS OF POTATO UNDER WINTER MAIZE + POTATO INTERCROPPING SYSTEM
}

\author{
VK Verma*, RN MEena, GaUrav ${ }^{1}$ and MK Singh ${ }^{2}$ \\ Department of Agronomy, Institute of Agricultural Sciences, \\ Banaras Hindu University-Varanasi (UP) 221005, India \\ Keywords:Nutrient uptake, Protein, Starch, Vermicompost, Poultry manure
}

\begin{abstract}
Effects of crop geometry and nutrient management on nutrient uptake and quality parameters of potato under winter maize + potato intercropping system were studied during two consecutive years (2015-2016 and 2016-17) at BHU, Varanasi, India. Results revealed that under different crop geometry the nutrient uptake (NPK kg/ha) were obtained significantly higher with $1: 2$ row ratio in additive series as compared to other row ratio due to maximum plant population. The minimum nutrient uptake (NPK kg/ha) were obtained with 1:1 row ratio in replacement series. However, quality parameters (protein and starch) did not vary significantly by different crop geometry during both the years of investigation. Amongst nutrient management, the highest nutrient uptake (NPK kg/ha) and quality parameters (protein and starch) were obtained significantly with the application of $100 \% \mathrm{RDF}+25 \% \mathrm{~N}$ through poultry manure followed by the application of $100 \% \mathrm{RDF}+25 \% \mathrm{~N}$ through vermicompost. Thus, the results suggest that 1:2 row ratio (crop geometry) in additive series with $100 \% \mathrm{RDF}+25 \% \mathrm{~N}$ through poultry manure (nutrient management) followed by $100 \% \mathrm{RDF}+25 \% \mathrm{~N}$ through vermicompost were feasible and practicable during both the years of investigations.
\end{abstract}

\section{Introduction}

Potato being an economical food provides low-cost energy to the human diet because it is rich in starch, vitamin (C and B) and minerals. It contains 20.6 carbohydrates, 2.1 protein, 0.3 fat, 1.1 crude fiber and $0.9 \%$ ash. It also contains good amounts of essential amino acids like leucine, tryptophane and isolucine (Khurana and Naik 2003). India produced $43.42 \mathrm{mt}$ potato from $2.12 \mathrm{~m}$ ha area with an average productivity of $20.5 \mathrm{~m} \mathrm{t} / \mathrm{ha}$ (DAC \& FW, 2015-16). In UP, potato is grown in an area of $0.61 \mathrm{~m}$ ha, with an annual production of $13.91 \mathrm{~m} t$ and average productivity of $22.81 \mathrm{~m} \mathrm{t} / \mathrm{ha}$ (Anonymous 2017). It is grown in almost all the states in India and under different agroclimatic conditions. It involves high cost of cultivation due to its heavy requirements of seed, fertilizers and other management practices. The nutritional requirement of the crop is much more for its high bulking rate.

A major benefit of intercropping is the increase in production per unit area compared to sole cropping through the effective use of resources, including water, nutrients and solar energy (Nasriet al. 2014). Since, maize is a widely spaced crop, inter- row space could profitably be utilized for other crops particularly in winter season. This approach may increase the possibility to generate the yield recovery of such system. Because in north India the growth of winter maize, up to the middle of December remains normal and thereafter due to low temperature it almost ceases till middle of February, leaving enough scope for intercropping during this period to get more returns from an unit area of land. There are many winter crops which may be suitably adjusted in between two rows of winter maize.

*Author for correspondence: <vermaagribhu@gmail.com>. ${ }^{1}$ Banda University of Agriculture and Technology, Banda 210001, Uttar Pradesh, India. ${ }^{2}$ Department of Horticulture, Institute of Agricultural Sciences, Banaras Hindu University-Varanasi (UP) India-221005. 
Organic manures like farm yard manure (FYM), poultry manure (PM) and vermicompost (VC) play an important role in potato productivity. These sources can reduce the mining of soil nutrient and improve soil organic matter, humus and overall soil productivity (Jenssen 1993). Shuklaet al. (2013) also reported that use of organics in association with chemical fertilizers is superior to its individual components. The use of readily available vermicompost and farmyard manure with suitable strain of Azotobacterand phosphate solubilizing bacteria in a crop, like maize in conjugation with chemical fertilizers can help in achieving the productivity and sustainability of crop production and soil health. Keeping all these facts in view, effects of crop geometry and nutrient management on nutrient uptake and quality parameters of potato under winter maize + potato intercropping system were investigated.

\section{Materials and Methods}

A field experiment was conducted during the winter (rabi) season of 2015-2016 and 2016-17 at the Agricultural Research Farm, Institute of Agricultural Sciences, Banaras Hindu UniversityVaranasi (UP). It is situated in the South-Eastern part of Varanasi. Geographically, experimental site falls under sub-tropical zone of Indo-Gangatic plains and lies on the left bank of river Ganga. It is located on $25^{\circ} 15^{\prime} 19.7^{\prime \prime} \mathrm{N}$ latitude, $82^{\circ} 59^{\prime} 34.2^{\prime \prime} \mathrm{E}$ longitude and at an altitude of 76 meters above mean sea level. Varanasi falls in the belt of semi-arid to sub-humid climate receiving a mean assured rainfall of more than $1100 \mathrm{~mm}$ and potential evapotranspiration of about $1525 \mathrm{~mm}$, thus causing a moisture deficit of $425 \mathrm{~mm}$. The mean weekly maximum temperature varied from 19 to $30.04^{\circ} \mathrm{C}$ with an average of $24.97^{\circ} \mathrm{C}$ during $2015-16$, and 20.10 to $29.0^{\circ} \mathrm{C}$ with an average of $23.82^{\circ} \mathrm{C}$ during $2016-17$ in the crop cycle of potato. The weekly mean minimum temperature ranges from 7.20 to $17.20^{\circ} \mathrm{C}$ with an average of $12.05^{\circ} \mathrm{C}$ during $2015-16$, and 8.20 to $16.30^{\circ} \mathrm{C}$ with an average of $11.69^{\circ} \mathrm{C}$ during $2016-17$ in the crop cycle of potato. The experimental soil was sandy clay loam, $\mathrm{pH}$ (7.45), EC (0.18) dSm/1 organic carbon $(0.36 \%)$, bulk density $(1.37 \mathrm{~g} / \mathrm{cc})$ particle density $(2.61 \mathrm{~g} / \mathrm{cc})$, available $\mathrm{N}(199.89 \mathrm{~kg} \mathrm{ha} / 1), \mathrm{P}(20.28 \mathrm{~kg} \mathrm{ha} / 1)$ and $\mathrm{K}(205.66 \mathrm{~kg}$ ha/1). The field experiment carried out in split -plot design with 3 replications. The main plot treatments consisted of 4 crop geometry, viz. 1:1 and 1:2 row ratio in replacement series as well as in additive series having two different spacings $60 \times 20 \mathrm{~cm}$ in replacement series and $75 \times 20 \mathrm{~cm}$ in additive series and the sub plot treatments consisted of 5 nutrient management viz. 100\% RDF, $100 \% \mathrm{RDF}+25 \% \mathrm{~N}$ through vermicompost, $100 \% \mathrm{RDF}+25 \% \mathrm{~N}$ through poultry manure, $75 \%$ $\mathrm{RDF}+25 \% \mathrm{~N}$ through vermicompost + Azotobacter and $75 \% \mathrm{RDF}+25 \% \mathrm{~N}$ through poultry manure + Azotobacter were taken during both the years of field investigation. All the nutrients were calculated on the basis of plant population $\mathrm{ha}^{-1}$ of both crops. Half dose of nitrogen and full dose of phosphorus and potash were applied at the time of sowing/planting and remaining half dose of the nitrogen was applied at knee high stage of maize as well as earthing up of potato. Bulky organic manure (Vermicopost and poultry manure) was applied as per treatments over the plot. The late maturing variety of maize hybrids 'DKC-9081' and medium maturing variety of potato KufriBadshah were taken as test materials during both the years of experimentation. Seed/tuber of maize and potato were sown in second fortnight of November. Azotobacter were used to inoculate the maize seeds and potato tubers as per the treatment. For maize, a slurry was prepared by boiling $100 \mathrm{~g}$ jaggary in one litre of water. After cooling, one packet bio-fertilizer containing $200 \mathrm{~g}$ culture was dissovled to the gur mixture for seed treatment of maize about $10 \mathrm{~kg}$ and for potato tubers, Azotobacterchroococumculture solution was prepared by mixing $50 \mathrm{~g}$ bacterial culture and $100 \mathrm{~g}$ jaggary in one litre of water and stirred well. The solution was sprayed over $25 \mathrm{~kg}$ well sprouted tubers of potato and mixed with hand so that uniform and even spray of bio-fertilizer over the tubers is achieved. The tubers were planted in the field after drying in shade. 
Plant samples of tuber and haulm were taken for biochemical analysis. The dried samples were grounded in a micro Willey - Mill and passed through 40 mesh sieves. The ground materials were collected in butter paper bags and were analyzed for nitrogen, phosphorus and potassium contents. Starch and crude protein were also analyzed for tuber samples.Based on the nutrient content in haulms and tuber at harvest of the crop, the uptake of NPK of potato was worked out and expressed in $\mathrm{Kg} \mathrm{ha}^{-1}$ using the following formula.

$$
\text { Nutrient uptake }(\mathrm{kg} / \mathrm{ha})=\frac{\begin{array}{c}
\text { Nutrient content }(\%) \text { in grain } / \text { straw } \times \\
\text { grain / straw yield }(\mathrm{kg} / \mathrm{ha})
\end{array}}{100}
$$

The starch content of plant samples was estimated as per the procedure given for reducing sugars by Somogys method and glucose was used as a standard. The amount of glucose equivalent was multiplied by 0.9 to get starch content (Powell 1973).Crude protein content in grain was worked out by multiplying the nitrogen content in grain with the factor 6.25 , as suggested by A.O.A.C. (1970). Protein yield was determined by multiplying the protein content in grain with their respective yields.

$$
\text { Protein yield }(\mathrm{kg} / \mathrm{ha})=\frac{\text { Protein content }(\%) \times \text { Grain yield }(\mathrm{kg} / \mathrm{ha})}{100}
$$

The observations recorded during the course of investigation were tabulated and analyzed statistically to draw a valid conclusion. The data were analyzed by ANOVA as described by Gomez and Gomez (1984).

\section{Results and Discussion}

Data pertaining to N, P and $\mathrm{K}$ uptake $(\mathrm{kg} / \mathrm{ha})$ and total uptake $(\mathrm{kg} / \mathrm{ha})$ in tuber and haulms of potato crop under the influence of crop geometry and nutrient management practices are presented in Tables 1, 2 and 3. Among all the crop geometry, the nitrogen uptake in tuber (264.02 in 201516 and 277.41 in 2016-17) and haulms (112.86 in 2015-16 and 114.95 in 2016-17) were recorded significantly highest with 1:2 row ratio in additive series as compared to other row ratio. However, the minimum nitrogen uptake (kg/ha) in tuber (135.73 in 2015-16 and 141.14 in 2016-17) and haulms (51.48 in 2015-16 and 52.75 in 2016-17) were recorded with 1:1 row ratio in replacement series during both the years of investigation (Table 1). Data on phosphorus uptake in tuber and haulms presented in Table 2 showed maximum phosphorus uptake $(\mathrm{kg} / \mathrm{ha})$ in tuber $(74.65$ in 201516 and 81.26 in 2016-17) and haulms (22.94 in 2015-16 and 25.23 in 2016-17) with 1:2 row ratio in additive series as compared to the rest of the treatments. However, the minimum phosphorus uptake (kg/ha) in tuber (38.67 in 2015-16 and 41.44 in 2016-17) and haulms (10.73 in 2015-16 and 11.61 in 2016-17) were recorded with 1:1 row ratio in replacement series during both the year of experimentation. Data presented in Table 3 revealed that potassium uptake $(\mathrm{kg} / \mathrm{ha})$ in tuber (346.06 in 2015-16 and 362.80 in 2016-17) and haulms (250.57 in 2015-16 and 254.98 in 201617) were significantly higher with 1:2 row ratio in additive series as compared to other row ratio. Nutrient uptake is a product between nutrient concentration and dry matter accumulation. Nutrient uptake was enhanced by wider row $(75 \mathrm{~cm})$ spacing than narrow row $(60 \mathrm{~cm})$ spacing. Improved uptake of NPK might be attributed to higher dry matter accumulation with $75 \mathrm{~cm}$ wider row spacing leading to higher uptake of N. Generally, when the uptake of N is more, the crop would have a tendency to absorb more P and K. Similar results of increased uptake of NPK due to wider row spacing were reported by Thavaprakash and Velayudham (2007). 


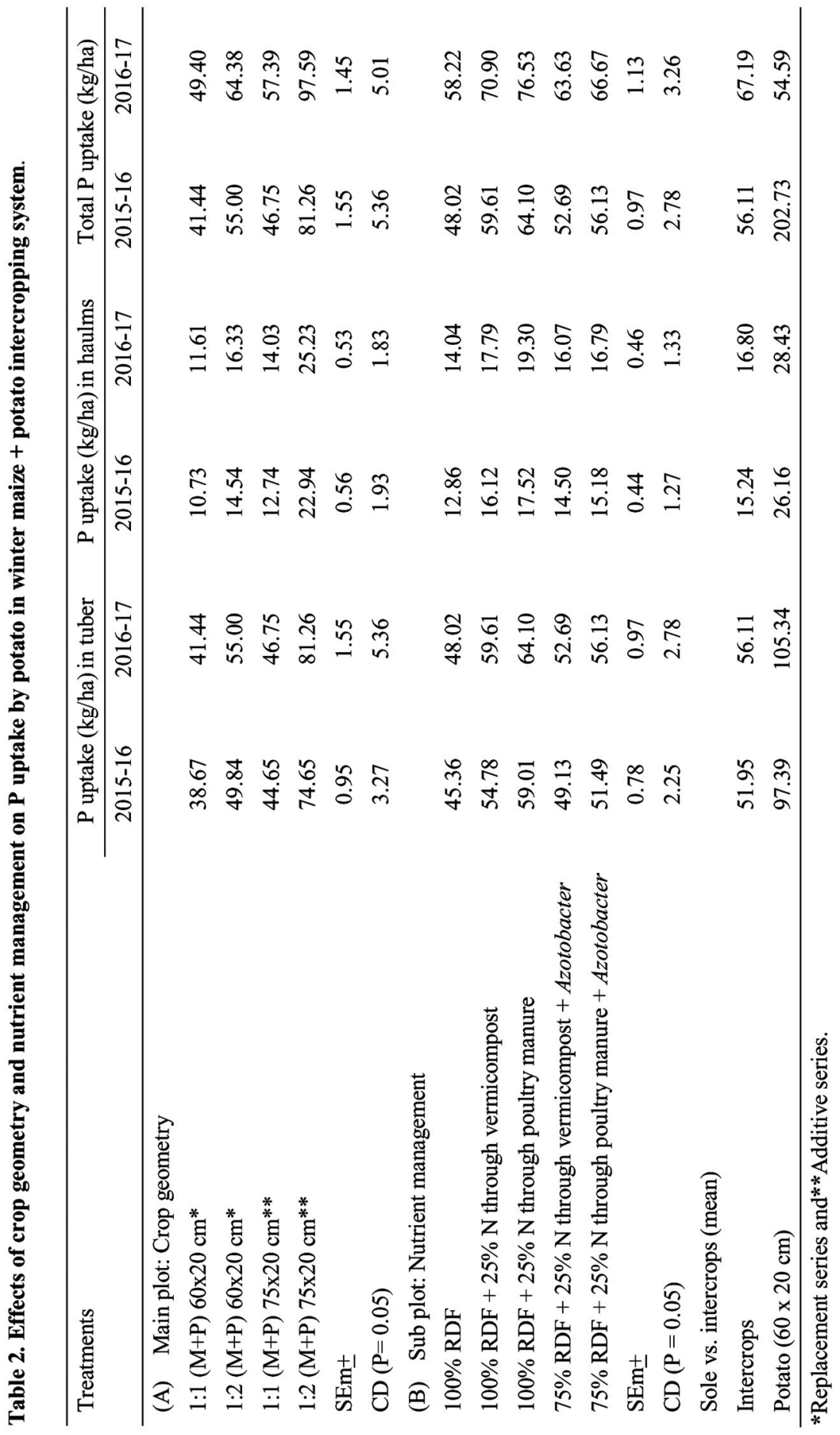




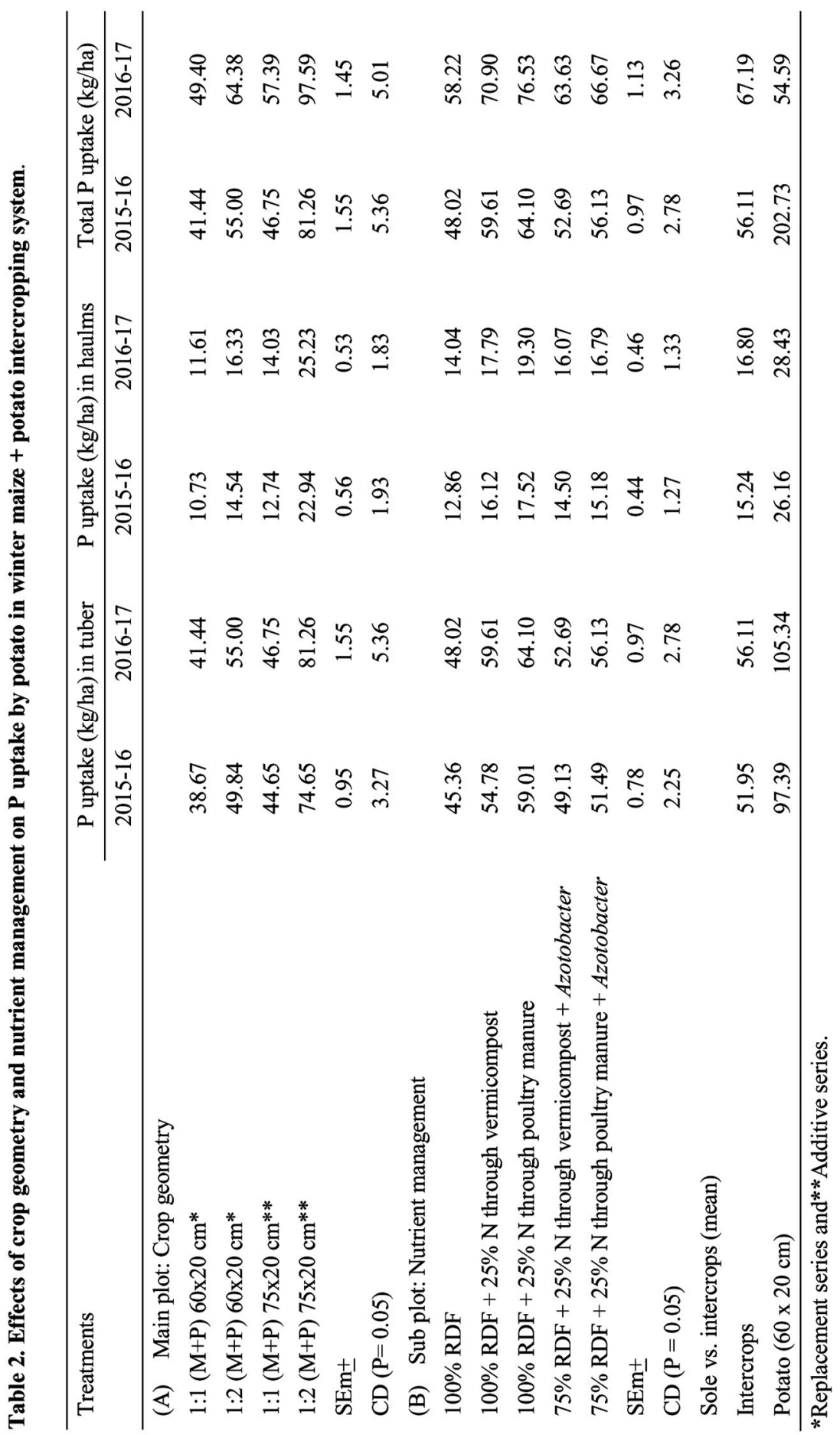




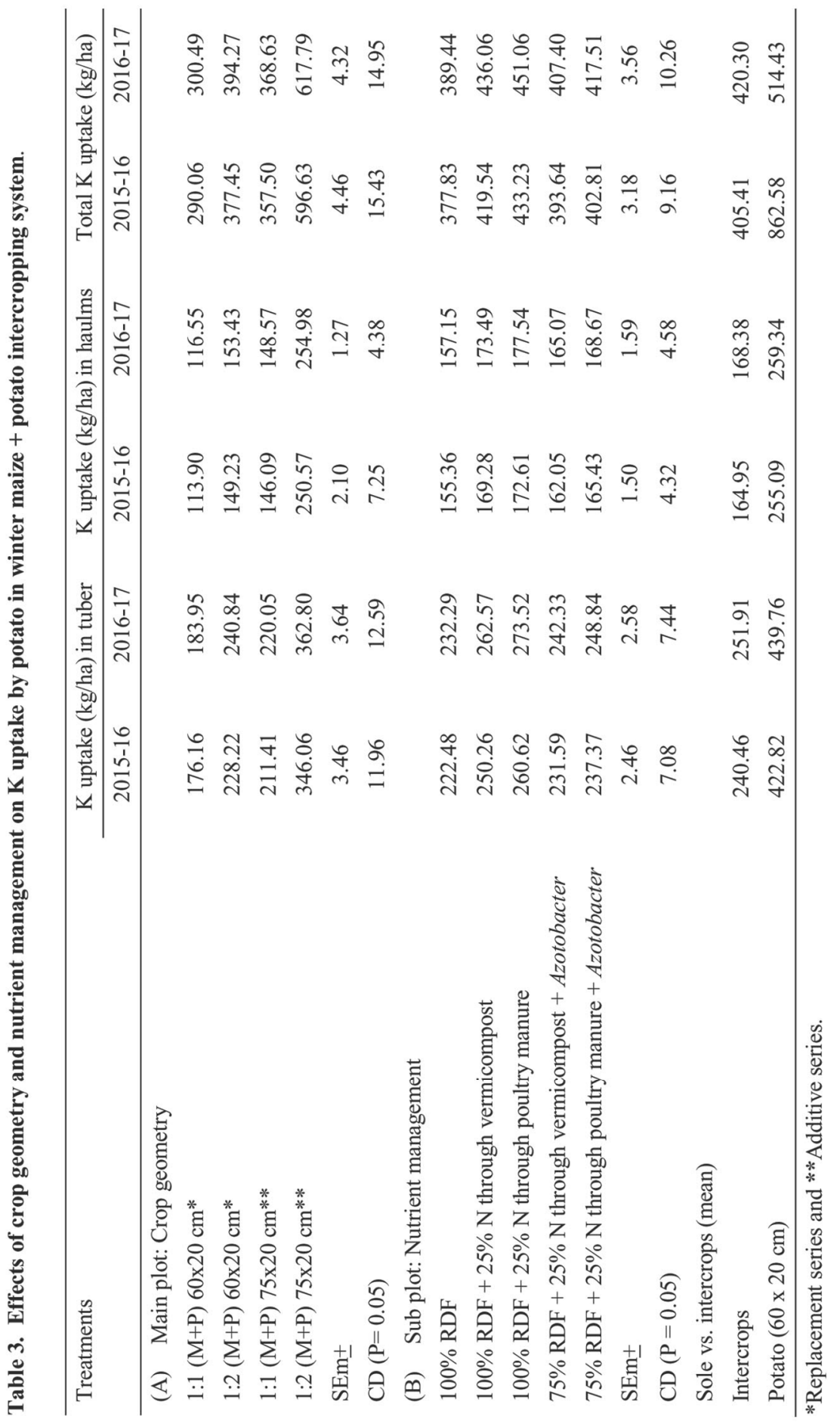




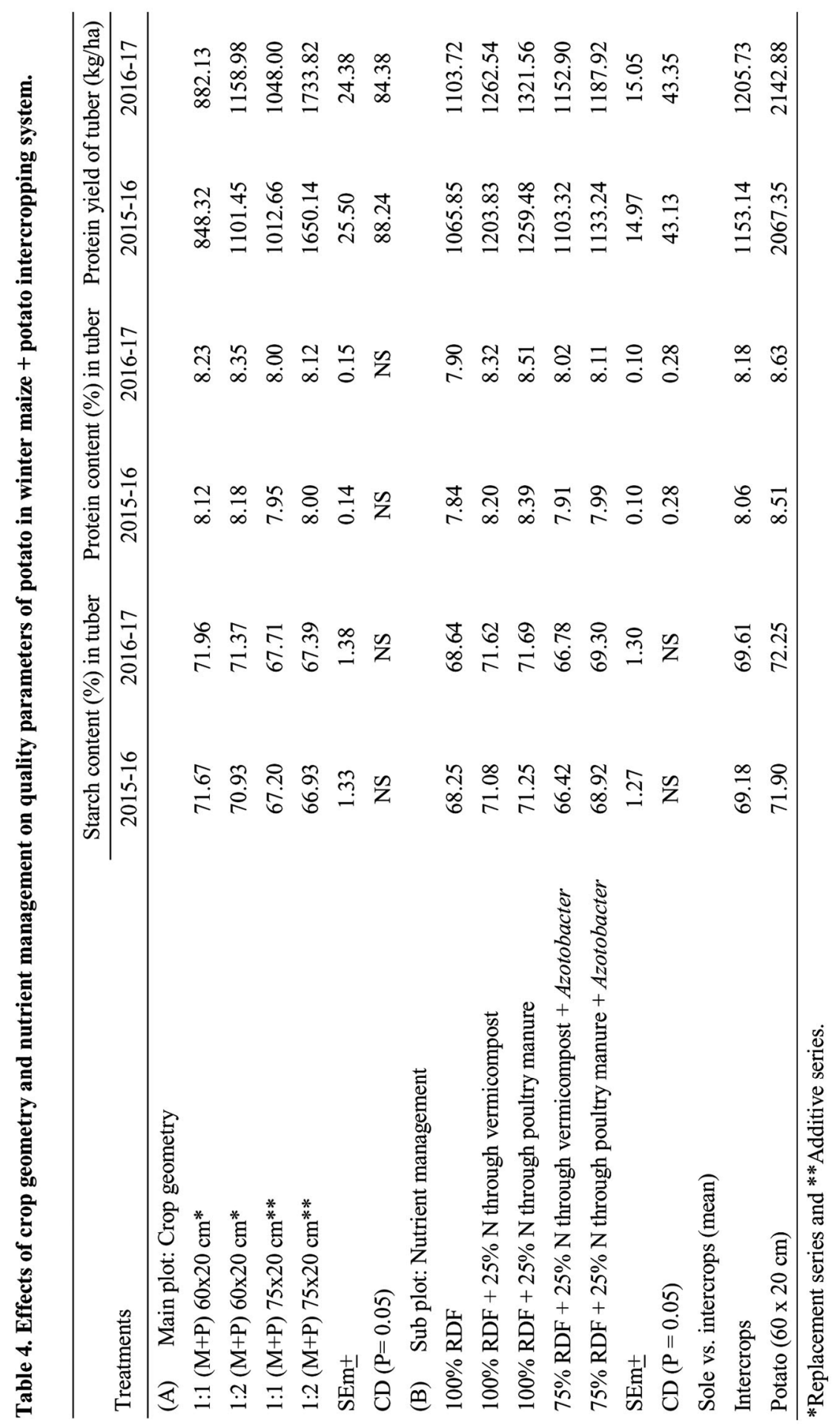


Significantly the highest nitrogen uptake (kg/ha) in tuber (201.52 in 2015-16 and 211.45 in 2016-17) and haulms (78.85 in 2015-16 and 81.27 in 2016 -17) were found with the application of $100 \% \mathrm{RDF}+25 \% \mathrm{~N}$ through poultry manure as compared to other treatments. However, the minimum nitrogen uptake (kg/ha) in tuber (170.54 in 2015-16 and 176.60 in 2016-17) and haulms (68.49 in 2015-16 and 69.34 in 2016-17) were recorded with the application of 100\% RDF during both the years of investigation (Table 1). A critical analysis of the data showed that the highest phosphorus uptake (kg/ha) in tuber (59.01 in 2015-16 and 64.10 in 2016-17) and haulms (17.52 in 2015-16 and 19.30 in 2016-17) were with the application of $100 \% \mathrm{RDF}+25 \% \mathrm{~N}$ through poultry manure as compared to other treatments during both the years of experimentation (Table 2). Data presented in Table 3 reveals that potassium uptake ( $\mathrm{kg} / \mathrm{ha}$ ) in tuber (260.62 in 2015-16 and 273.52 in 2016-17) and haulms (172.61 in 2015-16 and 177.54 in 2016-17) were the highest with the application of $100 \% \mathrm{RDF}+25 \% \mathrm{~N}$ through poultry manure as compared to other treatments during both the years of experimentation. Favourable effect of integrated nutrient management using inorganic fertilizers and organic manures on increasing the uptake of $\mathrm{N}, \mathrm{P}$ and $\mathrm{K}$ by potato was also noticed by Kumar et al. (2008) and Baishya (2009). Among all the nutrient management practices, the highest total NPK uptake (kg/ha) were observed with the application of $100 \% \mathrm{RDF}+$ $25 \% \mathrm{~N}$ through poultry manure as compared to other treatments during both the years of investigation.On the basis of mean, the maximum NPK uptake $(\mathrm{kg} / \mathrm{ha})$ were recorded in sole potato as compared to intercrops.

A critical analysis of the data pertaining to starch content (\%) in tuber are presented in Table 4. Under different crop geometry, the starch content (\%) and protein contents (\%) in tuber were found to be non-significant during both the years. Similarly, Thavaprakaashet al. (2008) also did not find any variation due to varied crop geometry on fodder quality characters of maize due to varied level of spacing. Amongst the nutrient management practices starch content in tuber was also recorded non-significant during both the years. However, the highest protein content was recorded with the application of $100 \% \mathrm{RDF}+25 \% \mathrm{~N}$ through poultry manure, on par with the application of $100 \% \mathrm{RDF}+25 \% \mathrm{~N}$ through vermicompost as compared to rest of the treatments during both the years of investigation. On the basis of mean, the highest starch and protein content in tubers were found in sole potato as compared to intercrops during both the years.

Data pertaining to protein yield in tuber $(\mathrm{kg} / \mathrm{ha})$ are presented in Table 4 . The protein yield in tubers was recorded significantly higher with 1:2 row ratio in additives series due to higher number of plant population as compared to other row ratio experimentation. Effects of nutrient management practices on protein yield in tubers was observed significantly higher with the application of $100 \% \mathrm{RDF}+25 \% \mathrm{~N}$ through poultry manure as compared to rest of the treatments during both the years of experimentation. Reddy et al. (1999) and Mehta et al. (1996) also reported that application of poultry and and goat manures improved the soil fertility environment, which led to enhanced physiological and biochemical reaction in plants ultimately improving the fodder quality of baby corn due to organic manures. On the basis of mean, the highest protein yield in tuber was obtained in sole potato as compared to inter crops during both the years of experimentation.

Results of the present study was found to be feasible and viable to grow the winter maize with potato in 1:2 row ratio under additive series $\left(75 \times 20 \mathrm{~cm}^{2}\right)$ along with the application of $100 \% \mathrm{RDF}$ $+25 \% \mathrm{~N}$ through poultry manure for obtaining higher nutrient uptake and quality parameters of potato. 


\section{References}

Anonymous 2017. Horticultural statistics at a glance, department of agriculture \& cooperation, ministry of agriculture and farmers welfare, New Delhi. pp. 213.

AOAC 1970. Official methods of analysis of the Association of Official Agricultural Chemists. Washington, D.C. pp. $18-19$.

Baishya LK 2009.Response of potato varieties to organic and inorganic sources of nutrients.Ph D thesis submitted to Visva- Bharati University, Santiniketan, West Bengal. pp. 99-102.

Gomez KA and Gomez AA 1984.Statistical Procedures in Agricultural Research, 2nd edition New York, Chichester, etc.Wiley, paperback, pp. 680.

JenssenBH 1993. Integrated nutrient management: The use of organic and mineral fertilizer. In:The Role of Plant Nutrients for Sustainable Food Crop Production in Sub-Saharan Africa, eds. H Van Reuler and WH Prins, Leidschendam, The Netherlands: VKP. pp. 89-105.

Kumar M, Jadav MK and Trehan SP 2008.Contributing of organic sources to potato nutrition at varying nitrogen levels. (In:) Proceedings of Global Potato Conference, held during 9-12 December 2008 at New Delhi, India

Khurana SMP and Naik PS 2003. The Potato: An overview. In: The Potato: Production and Utilization in Sub-tropics, eds., SM Paul Khurana, JS Minas SK Pandey, pp. 1-14. New Delhi: Mehta Publishers.

Mehta AM, Upadhyay PN, Chada JR and Patel JB 1996. Effect of Integrated nutrient management on yield and quality of sugarcane (Saccharumofficinarum).Indian J. Agron.41: 176-178.

Nasri R, Kashani, Barary M, Paknejad F and Vazan S 2014.Nitrogen uptake and utilization efficiency and the productivity of wheat in double cropping system under different rates of nitrogen. Inter. J. Biosci. 4: 184-193.

Powell GJ 1973. Automated determination of reducing sugars, total sugars and starch in plant tissue from one weighed sample.JAOAC 56: 1419-1424.

Reddy BG and MS Reddy 1999. Effect of integrated nutrient management on soil available micro-nutrient in maize-soybean cropping system.J. Res.ANGRAU 27: 24-28.

Shukla SK, Awasthi SK, Singh R, Meena N, Gaur A and Singh AK 2013. Integrated nutrient management in sugarcane-based production systems: A review. Current Advan.Agricul. Sci. 5: 1-7.

Thavaprakash N and Velayudham K 2007.Effect of crop geometry, Intercropping Systems and INM Practices on Cob Yield and Nutrient Uptake of Baby Corn, Asian J. Agricul. Res. 1: 10-16.

Thavaprakaash N, Velayudham K and Muthukumar VB 2008.Response of Crop Geometry, Intercropping Systems and INM Practices on Yield and Fodder Quality of Baby Corn. Asian J. Scien. Res. 1: 153-159. 